\title{
Distribution of Asclepias Asymptomatic Virus and Exploration of Possible Effects on the Wild Plant Host, Asclepias viridis
}

\author{
Helen M. Alexander, ${ }^{1}$ Janette A. Steets, ${ }^{2}$ and Akhtar $\mathrm{Ali}^{3,+}$ \\ ${ }^{1}$ Department of Ecology and Evolutionary Biology, University of Kansas, Lawrence, KS 66045 \\ ${ }^{2}$ Department of Plant Biology, Ecology and Evolution, Oklahoma State University, Stillwater, OK 74078 \\ ${ }^{3}$ Department of Biological Science, The University of Tulsa, Tulsa, OK 74104
}

Accepted 20 December 2019.

\section{Abstract}

Viruses in wild plants are poorly studied yet important sources of emerging diseases. We surveyed populations of a perennial host, Asclepias viridis, for Asclepias asymptomatic virus (AsAV) in nine sites (two in Oklahoma, seven in Kansas) from 2015 to 2018. All collected leaf samples from $A$. viridis were tested serologically by dot-immunobinding assays. In Oklahoma, the virus was present and abundant at both sites; in Kansas, the virus was found in four sites, but only one or two plants were infected per site. We followed the fate of individual plants and found little evidence that plant persistence or reproduction differed among plants with and without virus infection. Infected plants were $20 \%$ shorter than noninfected plants in two years at one site. No symptoms were evident in virus-infected plants. We observed apparent gains and losses of infection across years in Oklahoma but not in Kansas. The apparent neutral to slightly negative effects of this virus on this wild host emphasize the importance of studying wild plant-wild virus interactions to more fully understand plant virus ecology. Further, the fact that the virus is known to cause symptoms in plants of economically important families emphasizes the applied importance of research on wild viruses.

Keywords: virology, wild plants, wild viruses, plant virus ecology, Asclepias asymptomatic virus, Asclepias viridis
Most plant viruses were first identified in crops (Wren et al. 2006), but there is increasing documentation of diverse viruses associated with plants outside of agricultural crops (Roossinck et al. 2010; Shates et al. 2019; Susi et al. 2019; Thapa et al. 2015). Some of the earliest studies in virology focused on these viruses in the context of virus and vector reservoirs: weedy plants, for example, may harbor viruses or vectors that can spread into nearby crop fields (Duffus 1971). Movement of viruses between crop and noncrop areas could lead to emerging virus diseases in agriculture or in conservation areas (Jones 2009). In most cases, however, our knowledge of viruses of wild (nonagricultural) plants is extremely limited, and thus we lack understanding of the factors that affect their occurrence in natural ecosystems. Specifically, we have little knowledge of the prevalence and distribution of these viruses and virus effects on plant growth, survival, and reproduction.

In a review of 20 field studies of crop-associated viruses, virus infection primarily has negative effects on wild plant fitness (Malmstrom and Alexander 2016). However, it is possible that viruses that are not typically associated with crop plants may have quite different associations with their hosts. Roossinck and Bazán

\section{${ }^{\dagger}$ Corresponding author: A. Ali; Akhtar-ali@utulsa.edu}

Current address for J. A. Steets: Illumination Works, Beavercreek, OH 45431

*The $e$-Xtra logo stands for "electronic extra" and indicates that supplementary materials are published online.

The author(s) declare no conflict of interest.

(C) 2020 The American Phytopathological Society
(2017) have, for example, emphasized that wild viruses (typically viruses first discovered in noncultivated plants) may have neutral or positive effects on their host plants and few or no symptoms. However, there are few field studies that examine how wild viruses affect plant growth, survival, and reproduction. A rare exception is work by Gibbs (1980) with the tymovirus Kenneyda yellow mosaic virus (KYMV), in which infection led to stunting but greater survival because mammalian herbivores avoided infected plants.

We studied Asclepias asymptomatic virus (AsAV), a putative member of the family Tymoviridae, genus Tymovirus, that was first found in extensive surveys of the tallgrass prairie in Oklahoma (Min et al. 2012). Tallgrass prairies are dominated by $\mathrm{C} 4$ grasses such as Andropogon gerardii and Sorghastrum nutans; these ecosystems are highly diverse because of the presence of many species in the Asteraceae, Fabaceae, and other flowering plant families. Prairie ecosystems once extended across much of central North America, an area now dominated by agriculture. In most states (United States) and provinces (Canada), only 1 to $4 \%$ of the original tallgrass prairie remains (Samson and Knopf 1994), and prairie restorations are small in size. From work in Oklahoma prairies, the AsAV virus is known to infect 52 species of prairie plants with highest prevalence and titer in Asclepias viridis Walter (green antelopehorn, Apocynaceae) (Thapa et al. 2015, Melcher, personal communication).

Previous work by Min et al. (2012) showed that AsAV generally does not cause symptoms on $A$. viridis, although symptoms of chlorotic lesions or chlorosis associated with mottling were apparent with mechanical greenhouse inoculation on Chenopodium amaranticolor and Nicotiana benthamiana, respectively. In field studies, AsAV occurred in the underground caudex of the plant during the winter, suggesting that it could overwinter with the plant 
(Min et al. 2012). Although details of virus transmission are unknown, extracts of red milkweed beetles visiting A. viridis had AsAV sequences (Min et al. 2012) and could be a potential vector. Cloning of the virus genome revealed its close association to KYMV (Min et al. 2012).

The objective of this study was twofold: (i) to gain a better knowledge of the spatial distribution of the virus by increasing the number of host populations sampled and sampling populations in new geographic areas and (ii) to determine if there is an association between virus detection/lack of detection and plant persistence, plant size, and plant reproduction by following the fate of individual plants from 2015 to 2018 .

\section{Collection of Plant Samples in Oklahoma and Kansas}

In June 2015, 30 leaf samples of $A$. viridis plants from nine sites (two in Oklahoma and seven in Kansas) (Table 1) were collected. Each leaf sample was collected from a distinct individual. Although the site history of the two Oklahoma sites and Kansas site 4 (Table 1, "Grassland - A") is unknown, it is likely that these sites were prairie restorations or areas naturally colonized by prairie plants. The other Kansas sites were never plowed (remnant) prairies (Table 1, "Grassland - B"). Although the Kansas Flint Hills still has extensive prairie remnants, our work was done further east where little unplowed prairie remains (e.g., 0.5\% prairie in Douglas County, KS; Kindscher et al. 2016). Based on the Universal Transverse Mercator coordinates of each site, we calculated the Euclidean distance between sites (see Table A in the supporting materials). For all sites, we located plants for this study by thorough searches in defined areas in 2015 and using all $A$. viridis plants that were found in our research (see the supporting materials for site details).

From each plant, one expanded leaf directly below the apical meristem was removed, placed in a sealed plastic bag, and kept on ice until the leaves were transported via FedEx next-day delivery to the laboratory at the University of Tulsa, Oklahoma, for virus detection. Each plant that was sampled in 2015 was permanently marked in the field. We made similar leaf collections from persisting plants in May and early June in 2016 (all sites) and in 2018 (two Oklahoma sites, one Kansas site). We are confident of our ability to relocate plants over years because of our field methods. Specifically, for the Oklahoma sites, we put metal tags into the soil very close to each plant; $15-\mathrm{cm}$ metal staples held the tags permanently in the soil. Additionally, an expandable plastic ring was permanently labeled with the plant identification number and attached to one of the stems of each tagged plant. For the Kansas sites, we used similar metal tags as well as plastic labels and flags. Because of the larger size of the Kansas sites, we also made sketch maps showing locations and distances between plants. If we could locate a metal tag in 2016 to 2018, but did not observe a plant, we recorded the plant as not being found in that year. As noted later, plants occasionally were not found one year but were found a subsequent year; thus, we refer to data on plant persistence, not survival.

\section{Detection by Dot-Immunobinding Assay}

All samples were tested serologically using dot-immunobinding assay (DIBA) as previously reported (Ali et al. 2012). Briefly, samples were prepared for DIBA by aliquoting approximately $100 \mathrm{mg}$ of tissues from each leaf sample into individual plastic bags. The tissues from each sample were crushed individually with one volume of phosphate-buffered saline buffer at room temperature. Extracted sap from each sample was transferred to a 1.5-ml tube and centrifuged for $2 \mathrm{~min}$, and then $2 \mu \mathrm{l}$ was dotted on the nitrocellulose membranes. Membranes were air-dried and processed immediately or stored at $4^{\circ} \mathrm{C}$ for later processing.

Each dotted membrane was developed according to the procedure mentioned previously (Ali et al. 2012), except in step two, in which antisera specific to AsAV (prepared by GenScript USA, Inc., in rabbits using purified virus particles of AsAV) was added to the membranes at a dilution of 1:1,000. Results were analyzed qualitatively based on the presence and absence of the positive samples. At least 28 DIBA-negative plants along with five DIBA-positive samples as a positive control (data not shown) were also confirmed by reverse transcription polymerase chain reaction using coat protein gene-specific primers against AsAV as previously described (Min et al. 2012).

For simplicity, plants in which the virus was detected were labeled as "infected" (V+), and those in which the virus was not detected were labeled as "noninfected" (V-).

\begin{tabular}{|c|c|c|c|c|c|c|}
\hline \multicolumn{7}{|c|}{$\begin{array}{l}\text { TABLE } 1 \\
\text { Site location, number of plants with virus detection, and total sampled plants }{ }^{\mathrm{a}}\end{array}$} \\
\hline State & Site type & Site number & Latitude, longitude & \multicolumn{3}{|c|}{ Virus detection/total sampled plants } \\
\hline Oklahoma & Grassland - A & Site 1 & $36.1011^{\circ} \mathrm{N}, 97.2094^{\circ} \mathrm{W}$ & $4 / 31^{b}$ & $5 / 24$ & $6 / 26$ \\
\hline Oklahoma & Grassland - A & Site 2 & $36.1238^{\circ} \mathrm{N}, 97.2106^{\circ} \mathrm{W}$ & $6 / 30$ & $16 / 40^{\mathrm{c}}$ & $17 / 33$ \\
\hline Kansas & Grassland - B & Site 1 & $38.1819^{\circ} \mathrm{N}, 95.2698^{\circ} \mathrm{W}$ & $0 / 30$ & $0 / 19$ & $-^{\mathrm{d}}$ \\
\hline Kansas & Grassland - A & Site 4 & $38.8268^{\circ} \mathrm{N}, 95.1476^{\circ} \mathrm{W}$ & $2 / 30$ & $2 / 30$ & $2 / 27$ \\
\hline Kansas & Grassland - B & Site 5 & $38.8667^{\circ} \mathrm{N}, 95.6460^{\circ} \mathrm{W}$ & $2 / 28$ & $2 / 28$ & - \\
\hline Kansas & Grassland - B & Site 6 & $38.4969^{\circ} \mathrm{N}, 96.3335^{\circ} \mathrm{W}$ & $2 / 28$ & $1 / 23$ & - \\
\hline Kansas & Grassland - B & Site 7 & $38.4993^{\circ} \mathrm{N}, 96.3339^{\circ} \mathrm{W}$ & $0 / 26$ & $0 / 28$ & - \\
\hline
\end{tabular}

${ }^{\text {a }}$ Grassland $-\mathrm{A}=$ history unknown, but these sites were likely prairie restorations or naturally colonized by prairie plants; and Grassland $-\mathrm{B}=$ never plowed (remnant) prairie.

$\mathrm{b}$ The number of sampled plants at a site changed between years because labeled plants were not always found every year, with losses due to either mortality, dormancy, or herbivory.

${ }^{c}$ The increase in sampled plants at Oklahoma site 2 in 2016 reflects the fact that 13 plants at this site were labeled in 2015 but not sampled for virus presence; the majority of these plants were infected in 2016 and 2018, leading to a large change in numbers.

${ }^{\mathrm{d}}$ Dash refers to sites that were not sampled in 2018. 


\section{Virus Presence in Oklahoma and Kansas}

Both Oklahoma sites had virus infection in all years, whereas the virus was only detected at four of the seven Kansas sites. At these four Kansas sites, only one or two plants were virus infected (Table 1, Fig. 1).

In Kansas, the few plants that were infected in one year were also infected when they were sampled in subsequent years. We did not observe a shift from virus detection to nondetection or vice versa; in a few cases, infected plants in one year died prior to the next year. However, in Oklahoma, there was more variation. For example, of the 24 plants sampled at Oklahoma site 1 in 2015 and 2016, four 2015 noninfected plants were infected in 2016, and for two 2015 infected plants the virus was not detected in 2016. Similar apparent shifts in infection were seen from 2016 to 2018 at Oklahoma site 1. However, for Oklahoma site 2 there were no changes in infection status for plants assayed for the virus in 2015 and 2016. Further, all 13 infected plants in 2016 were still infected in 2018, and most noninfected plants (16/20) remained noninfected in 2018.

Given the small numbers of infected plants at any site in Kansas, we focused only on the Oklahoma sites to explore the relationship between infection status and plant persistence over time, plant size, and plant reproduction.

\section{Plant Persistence, Size, and Reproduction of Plants With and Without Virus Detection (Oklahoma)}

In May and early June of 2015, at the same time as leaves were collected for AsAV detection, we recorded the total number of stems, the height $(\mathrm{cm})$ of the tallest stem, and whether flowering stems were present. The latter is a proxy for plant reproduction. In May and early June of 2016, 2017, and 2018, we searched for the same individuals, and if found, recorded the same data. Note that in some cases we expect a plant that did not have stems was not dead but was dormant or had been browsed. We thus refer to plant persistence as opposed to survival of individuals, although in most cases a nonpersistent plant probably had died. It is important to emphasize that even though an infected plant may persist over a 2 -year period, this does not necessarily mean that the virus was detected both years. We also observed plants for any obvious symptoms such as mottling or chlorosis.

\section{Statistical Methods}

We used $\chi^{2}$ tests to compare infected and noninfected plants for persistence through time and to determine whether infection status affected whether plants had few or large numbers of stems and whether they did or did not produce any flowering stems. We used

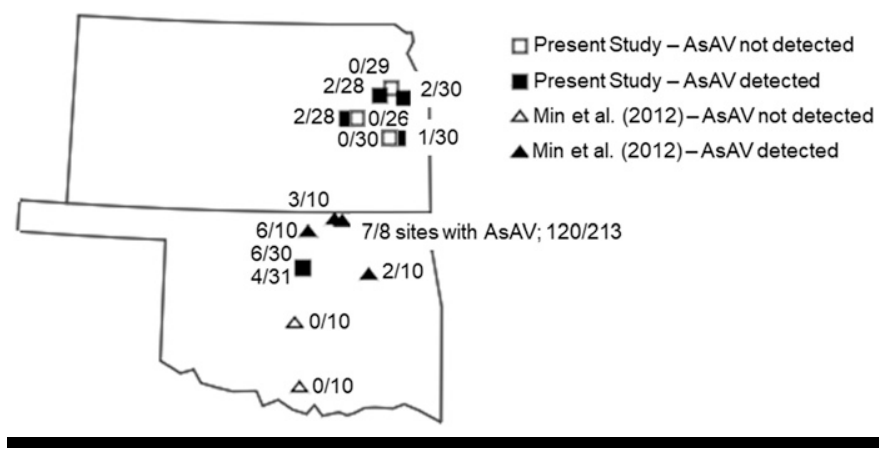

FIGURE 1

Number of virus-infected plants/total sampled plants at Oklahoma and Kansas sites in 2015 and past data on infection from Min et al. (2012). two sample $t$ tests to compare mean height of infected and noninfected plants.

\section{Plant Persistence Across Years, Plant Size, and Plant Reproduction}

Despite finding our metal tags in the field each year, individual plants were not observed in all years. For example, of the five 2016 $\mathrm{V}+$ plants at site 1 , only two were observed in 2017, yet all five were observed in 2018 (Table 2). There was no evidence that infection status in one year affected the likelihood of finding the plant in a later year; as seen in Table 2, plant persistence was relatively high in most years, and there was no consistent pattern with either noninfected or infected plants being more likely to be found again.

For most sites and years, virus-detected plants were no larger or smaller than plants in which the virus was not detected whether size was measured by the height of the tallest stem (Table 3 ) or stem number (Table 4). However, we did find significantly shorter infected plants in two years at one Oklahoma site; this site had the largest number of infected plants (Table 3 ). We found no evidence that the probability that a plant produced a flowering stem (and thus had the potential to reproduce) differed depending on infection status (Table 5).

No virus symptoms (e.g., mottling or chlorosis) were observed in our study.

\section{Conclusions and Recommendations}

Our study expands our knowledge of AsAV, a virus of the tallgrass prairie. Previous surveys had only been done in Oklahoma; our surveys of two new Oklahoma sites confirm that the virus is commonly found in the north central region of this state. We also found the virus in four of seven sites in Kansas, but few plants were infected per site. The factors affecting the distribution of the virus are not known. It is noteworthy that the highest infection has been seen at the Tallgrass Prairie Preserve (a 15,410-ha Oklahoma site with extensive prairie lands and high plant diversity) and areas nearby. In contrast, the prairie sites studied in Kansas were small and located in a landscape matrix of woodlands, hayfields, and pastures. These small sites may not have sufficient abundance of host plants to maintain the virus inoculum. AsAV has been documented in other species (Hackett et al. 2009; Muthukumar et al. 2009; Thapa et al. 2015), including prairie plants such as switchgrass (Panicum virgatum) that were present at our field sites. However, we expect that presence of large populations of $A$. viridis is particularly important for the virus to be maintained at a site. Melcher (unpublished), for example, found that although nucleotide sequences of AsAV were detected in 52 prairie plant species, $A$. viridis plants had the highest virus incidence and titer. It is also possible that vector densities and movement affect virus distributions. Tymoviruses are often beetle-transmitted, and virus extracts were found in beetles sampled from the plant (Ali, unpublished data; see Min et al. 2012). In future work it would be useful to survey $A$. viridis plants across their entire range (roughly an area defined by Nebraska to Texas to the west and Ohio to Florida to the east), as well as other host plants of the tallgrass prairie region.

The dynamics of infection appeared different in Oklahoma and Kansas. In Kansas, few plants were infected, but once the virus was detected in a plant, it was typically detected in future years. In contrast, we detected more infected plants in Oklahoma, but we observed more apparent gains and losses of the virus over the years. Min et al.'s (2012) work showed that two of the 24 plants with documented virus presence in one year had no virus detection the subsequent year. Our apparent higher rate of virus loss could reflect 
considerable deer browse at the Oklahoma sites, if infection was not found throughout the plant. Min et al. (2012) also showed high gains of the virus through time, particularly in one study site (10 of 25 plants negative for the virus in one year were positive the subsequent year). Although virus gains were observed in Oklahoma, we saw no such gains in Kansas. Our study thus suggests that rare dispersal events may introduce the virus into A. viridis populations in Kansas sites, but once present, the virus is maintained primarily by the fact that this host plant is long-lived (at least 10 years, Dee and Palmer 2017).
Perennial plants dominate natural ecosystems but have been understudied with respect to plant-virus interactions (Shates et al. 2019). By following labeled plants for 4 years, we found that detection or lack of detection of the virus was not associated with either increases or decreases in plant persistence or reproduction. At the Oklahoma site 2, where we had larger samples of infected plants, infected plants were $20 \%$ shorter than noninfected plants; it is possible that our small sample sizes of virus-infected plants reduced our statistical power for evaluation of virus effects. We also note that Oklahoma site 2 had less feeding by deer than Oklahoma

\begin{tabular}{|c|c|c|c|c|}
\hline \multicolumn{5}{|c|}{ 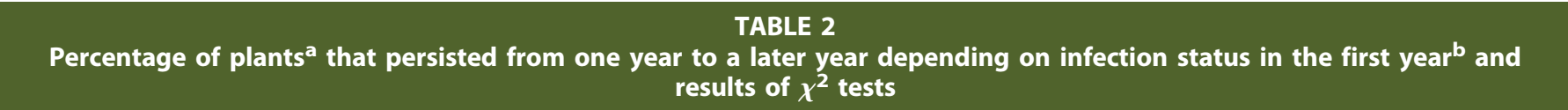 } \\
\hline Site number & Year & $\%$ of V-plants persisting & $\%$ of $\mathrm{V}+$ plants persisting & $\chi^{2}$ test results ${ }^{c}$ \\
\hline Oklahoma site 1 & 2015-2016 & $87.5 \%(24)$ & $75.0 \%(4)$ & - \\
\hline Oklahoma site 1 & 2016-2017 & $68.4 \%(19)$ & $40.0 \%(5)$ & - \\
\hline Oklahoma site 1 & 2016-2018 & $94.7 \%(19)$ & $100 \%(5)$ & - \\
\hline Oklahoma site 2 & 2016-2018 & $95.2 \%(21)$ & $81.3 \%(16)$ & $\chi^{2}=1.84, \mathrm{df}=1, P=0.17$ \\
\hline
\end{tabular}

${ }^{a}$ Number of plants studied is indicated in parentheses.

${ }^{\mathrm{b}} \mathrm{V}-=$ no virus detected; and $\mathrm{V}+=$ virus detected.

${ }^{c} \chi^{2}$ analyses were performed unless expected cell count(s) were less than five (indicated by "-"). Note that each line in the table summarizes a table with two rows ( $\mathrm{V}-$ or $\mathrm{V}+$ in a given year) and two columns (plant had or had not persisted in a subsequent year). Expected cell counts refer to number of plants expected under the null hypothesis that virus status and plant persistence were independent of each other.

\begin{tabular}{|c|c|c|c|c|}
\hline \multicolumn{5}{|c|}{$\begin{array}{c}\text { Mean } \pm \text { SE }^{\mathbf{a}} \text { of height }(\mathrm{cm}) \text { of tallest stem in Oklahoma sites depending on year and infection status }{ }^{\mathbf{b}} \text { and statistics from } \\
\text { a two-sample } t \text { test to compare mean height of } \mathrm{V}-\text { and } \mathrm{V}+\text { plants }\end{array}$} \\
\hline Site number & Year & Mean height $(\mathrm{cm})$ of V-plants & Mean height $(\mathrm{cm})$ of $\mathrm{V}+$ plants & $t$ test results \\
\hline Oklahoma site 1 & 2015 & $23.4 \pm 2.6(27)$ & $25.8 \pm 6.7(4)$ & $t_{29}=-0.33, P=0.74$ \\
\hline Oklahoma site 1 & 2016 & $20.5 \pm 8.4(19)$ & $17.7 \pm 6.9(5)$ & $t_{22}=0.69, P=0.50$ \\
\hline Oklahoma site 1 & 2018 & $20.0 \pm 1.9(20)$ & $18.0 \pm 3.7(6)$ & $t_{24}=0.50, P=0.63$ \\
\hline Oklahoma site 2 & 2018 & $38.4 \pm 2.9(16)$ & $30.1 \pm 2.9(17)$ & $t_{31}=2.04, P=0.05$ \\
\hline
\end{tabular}

${ }^{a}$ Number of plants studied is indicated in parentheses.

${ }^{\mathrm{b}}$ Virus infection status based on data from indicated year. $\mathrm{V}-=$ no virus detected; and $\mathrm{V}+=$ virus detected.

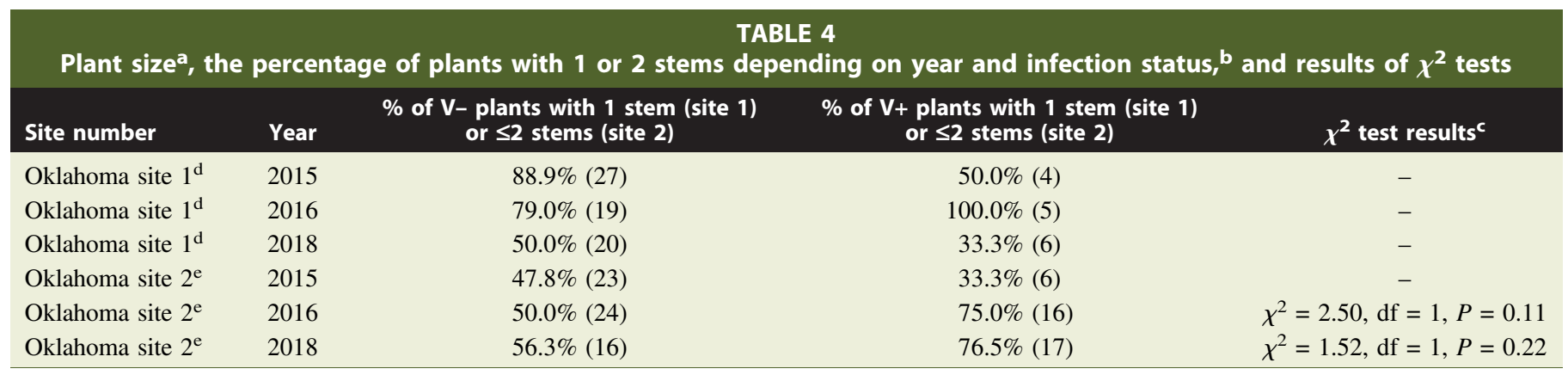

${ }^{a}$ Number of plants studied is indicated in parentheses.

${ }^{\mathrm{b}}$ Virus infection status based on data from indicated year. $\mathrm{V}-=$ no virus detected; and $\mathrm{V}+=$ virus detected.

${ }^{c} \chi^{2}$ analyses were performed unless expected cell count(s) were less than five (indicated by "-”). Note that each line in the table summarizes a table with two rows and two columns. Expected cell counts refer to number of plants expected under the null hypothesis that virus status and plant size were independent of each other.

${ }^{\mathrm{d}}$ Plants had from 1 to 3 stems at site 1 ; table values show the percentage of plants that had 1 stem.

e Plants had from 1 to 7 stems at site 2; table values show the percentage of plants that had 1 or 2 stems. 
Oklahoma site

${ }^{a}$ Number of plants studied is indicated in parentheses.

${ }^{\mathrm{b}}$ Virus infection status based on data from indicated year. $\mathrm{V}-=$ no virus detected; and $\mathrm{V}+=$ virus detected.

${ }^{c} \chi^{2}$ analyses were performed unless expected cell count(s) were less than five (indicated by "-"). Note that each line in the table summarizes a table with two rows and two columns. Expected cell counts refer to number of plants expected under the null hypothesis that virus status and flowering status were independent of each other.

site 1 , so potentially effects of the virus are more apparent when plants are not being fed on by mammalian herbivores.

Our discovery of an apparently neutral to slightly negative virus interaction with a wild host is consistent with the views of Roossinck and Bazán (2017) and more generally the widely held assumption that coevolution of virus and host populations in nonagricultural ecosystems leads to selection for minimal effects of virus infection on the host. However, the historical lack of communication between ecologists and virologists has meant that these assumptions have been largely untested (Malmstrom et al. 2011). Our study is unusual in providing data on plant persistence, growth, and reproduction in naturally infected versus noninfected plants of a wild plant in its field environment for a long (4-year) period.

We are aware, however, that confounding issues can occur with observational studies like ours. Consider, for example, a scenario in which the virus did have a negative effect on plant size, but this effect was not apparent because insect vectors were more likely to visit and thus infect larger plants. Future work on this system should include experimental approaches, as reviewed by Malmstrom and Alexander (2016). For example, one approach would be to identify young plants of $A$. viridis at field sites and do field inoculations with the virus (as well as mock-inoculation controls); these plants then could be followed in subsequent years for survival, growth, and reproduction, as well as for persistence of the virus. Although field inoculations have been done in ecological studies with viruses (Prendeville et al. 2014), they can be quite challenging. Alternatively, seedlings of $A$. viridis could be inoculated or mockinoculated in a greenhouse setting and then transplanted to a field site for demographic monitoring (following approaches such as Alexander et al. 2017). Inoculation studies should be paired with documentation of virus presence and titer at multiple locations within the plant. Such information is essential for understanding virus dynamics within plants and the possibility of virus compartmentalization, as well as guiding practical decisions such as the most reliable virus survey methodology (Lacroix et al. 2016).

Finally, we note that this study and that of Min et al. (2012) showed that plants of $A$. viridis that were infected by AsAV lacked symptoms. Although a lack of symptoms may seem consistent with an absence of virus effects on host plants, this is not necessarily true. For example, Alexander et al. (2017) documented no virus symptoms in switchgrass but found negative associations between virus infection and plant size and reproduction. Because of the unknown relationship between virus presence, presence/absence of symptoms, and virus effects on wild hosts, virus detection surveys need to be done without regard to plant appearance.
In general, AsAV is best known as an asymptomatic wild virus of the tallgrass prairie. Min et al. (2012) also showed that AsAV caused symptoms and likely reduced growth in greenhouse tests of C. amaranticolor (Chenopodiaceae, now Amaranthaceae) and $N$. benthamiana (Solanaceae). These plant families include several important crops, including beet, sugar beet, and chard. Further study of wild viruses thus is important for two reasons: to better understand their occurrence and dynamics in natural ecosystems and because of their potential importance as a pathogen of crop and garden plants.

\section{Acknowledgments}

We thank Oklahoma State University Department of Plant Biology, Ecology, and Evolution and Lake Carl Blackwell for access to field sites in Oklahoma and the University of Kansas Field Station, the Ross Natural History Reservation of Emporia State University, and private landowners (Guess family, McElroy family, Busby family) for access to field sites in Kansas. We appreciate support from Office of Research and Sponsored Programs, The University of Tulsa, Oklahoma, and Megan Withiam's assistance with field work at the Kansas sites. We appreciate thoughtful comments by two anonymous reviewers.

\section{Literature Cited}

Alexander, H. M., Bruns, E., Schebor, H., and Malmstrom, C. M. 2017. Cropassociated virus infection in a native perennial grass: Reduction in plant fitness and dynamic patterns of virus detection. J. Ecol. 105:1021-1031.

Ali, A., Mohammad, O., and Khattab, A. 2012. Distribution of viruses infecting cucurbit crops and isolation of potential new virus-like sequences from weeds in Oklahoma. Plant Dis. 96:243-248.

Dee, J. R., and Palmer, M. W. 2017. Annual rings of perennial forbs and mature oaks show similar effects of climate but inconsistent responses to fire in the North American prairie-forest ecotone. Can. J. For. Res. 47:716-726.

Duffus, J. E. 1971. Role of weeds in incidence of virus diseases. Annu. Rev. Phytopathol. 9:319-340.

Gibbs, A. 1980. Plant virus that partially protects its wild legume host against herbivores. Intervirology 13:42-47.

Hackett, J., Muthukumar, V., Wiley, G. B., Palmer, M. W., Roe, B. A., and Melcher, U. 2009. Viruses in Oklahoma Euphorbia marginata. Proc. Okla. Acad. Sci. 89:49-54.

Jones, R. A. C. 2009. Plant virus emergence and evolution: Origins, new encounter scenarios, factors driving emergence, effects of changing world conditions, and prospects for control. Virus Res. 141:113-130.

Kindscher, K., Martin, L. M., Staab, E. M., and Delisle, J. M. 2016. A natural areas inventory of Douglas County in Northeast Kansas. Open-File Report No. 184. Kansas Biological Survey, Lawrence, KS.

Lacroix, C., Renner, K., Cole, E., Seabloom, E. W., Borer, E. T., and Malmstrom, C. M. 2016. Methodological guidelines for accurate detection of viruses in wild plant species. Appl. Environ. Microbiol. 82:1966-1975.

Malmstrom, C. M., and Alexander, H. M. 2016. Effects of crop viruses on wild plants. Curr. Opin. Virol. 19:30-36. 
Malmstrom, C. M., Melcher, U., and Bosque-Perez, N. A. 2011. The expanding field of plant virus ecology: Historical foundations, knowledge gaps, and research directions. Virus Res. 159:84-94.

Min, B. E., Feldman, T. S., Ali, A., Wiley, G., Muthukumar, V., Roe, B. A., Roossinck, M., Melcher, U., Palmer, M. W., and Nelson, R. S. 2012. Molecular characterization, ecology, and epidemiology of a novel tymovirus in Asclepias viridis from Oklahoma. Phytopathology 102:166-176.

Muthukumar, F., Melcher, U., Pierce, M. L., Wiley, G. B., Roe, B. A., Palmer, M. W., Thapa, V., Ali, A., and Ding, T. 2009. Non-cultivated plants of the Tallgrass Prairie Preserve of northeastern Oklahoma frequently contain viruslike sequences in particulate fractions. Virus Res. 141:169-173.

Prendeville, H. R., Tenhumberg, B., and Pilson, D. 2014. Effects of virus on plant fecundity and population dynamics. New Phytol. 202:1346-1356.

Roossinck, M. J., and Bazán, E. R. 2017. Symbiosis: Viruses as intimate partners. Annu. Rev. Virol. 4:123-139.

Roossinck, M. J., Saha, P., Wiley, G. B., Quan, J., White, J. D., Lai, H., Chavarria, F., Shen, G., and Roe, B. 2010. Ecogenomics: Using massively parallel pyrosequencing to understand virus ecology. Mol. Ecol. 19: 81-88.

Samson, F., and Knopf, F. 1994. Prairie conservation in North America. Bioscience 44:418-421.

Shates, T. M., Sun, P., Malmstrom, C. M., Dominguez, C., and Mauck, K. E. 2019. Addressing research needs in the field of plant virus ecology by defining knowledge gaps and developing wild dicot study systems. Front. Microbiol. 9:3305.

Susi, H., Filloux, D., Frilander, M. J., Roumagnac, P., and Laine, A.-L. 2019. Diverse and variable virus communities in wild plant populations revealed by metagenomic tools. PeerJ 7:e6140.

Thapa, V., McGlinn, D. J., Melcher, U., Palmer, M. W., and Roossinck, M. J. 2015. Determinants of taxonomic composition of plant viruses at the Nature Conservancy's Tallgrass Prairie Preserve, Oklahoma. Virus Evol. 1: vev007.

Wren, J. D., Roossinck, M. J., Nelson, R. S., Scheets, K., Palmer, M. W., and Melcher, U. 2006. Plant virus biodiversity and ecology. PLoS Biol. 4:e80. 